\title{
Fluorescence Immunolocalization in Mitotic Chromosome Spreads from Maize Embryos
}

Jing-Han Liü, Ya-zhong Wang\#, Lin Chen\# and Yan He*

National Maize Improvement Center of China, China Agricultural University, Beijing, China

*For correspondence: yh352@cau.edu.cn

\#Contributed equally to this work

[Abstract] Immunolocalization is a necessary technique in the study of chromosome structure and function. It can provide important information for better understanding the relation between epigenetic modifications and chromosome condensation. In this protocol, we describe a way to localize and detect the distribution of histone $\mathrm{H} 3$ methylated at lysine 9 (inactive heterochromatin) in embryos at a period of 14 day-after-pollination (DAP). The protocol allows the observation of somatic cells in mitotic chromosome spreads.

Keywords: Immunolocalization, Mitotic, Maize, Plant, Embryo, Chromosome spread

[Background] Immunolocalization, a technique widely applied in cytogenetics, offers a great contribution to explore the structure of chromosomes. The development of cytogenetic techniques enables us to gain knowledge about spatial and temporal proceedings of a given protein in the whole cell (Fransz et al., 1998; De Paula and Techio, 2014). Epigenetic modifications regulate gene expression by affecting chromatin structure and function (Bannister and Kouzarides, 2011). Moreover, a number of studies indicated that pathways and patterns of epigenetic modification exhibit distinct properties in different species, including Arabidopsis, rice, and maize (Kim et al., 2009; Chen and Zhou, 2013; Capuano et al., 2014; Springer and Schmitz, 2017). Immunolocalization techniques benefit greatly to decipher the morphology and structure of chromosomes during each step of plant meiosis (Pawlowski et al., 2013). However, many proteins associated with chromatin are not expressed in tassels or ears during meiosis. Thus, somatic cells as materials were used to analyze the localization of proteins that are expressed in other plant tissues during mitosis. Analyzing the changes in those proteins and in epigenetic modifications between wild type and a mutant allows us to gain a deeper understanding in their functions. In summary, this method allows us to detect the spatial or temporal distribution of a given protein during mitosis, and identify the distribution of various epigenetic modifications attributing to the molecular function via mitotic chromosome spreads.

\section{Materials and Reagents}

1. Pipette tips (Eppendorf)

2. $2 \mathrm{ml}$ Eppendorf tubes (Eppendorf)

3. Scalpel

4. $13 \mathrm{~mm}$ coverslips (CITOGLAS, catalog number: 10212020C) 
5. Glass slides (CITOGLAS, catalog number: 10127105P)

6. Parafilm

7. $35 \mathrm{~mm}$ Petri dish

8. Staining jar

9. Slide incubator box (Solarbio, YA0764)

10. Plant Material: Maize plants from B73 pure inbred line

11. Paraformaldehyde concentration $16 \%$ in PBS (store at $4{ }^{\circ} \mathrm{C}$ ) (Sigma, catalog number: P6148)

12. Sodium chloride ( $\mathrm{NaCl}$ ) (Sigma, catalog number: $\mathrm{S} 3014$ )

13. Autoclaved water

14. $\mathrm{KCl}$ (Sigma, catalog number: $\mathrm{P} 9541$ )

15. $\mathrm{Na}_{2} \mathrm{HPO}_{4}$ (Sigma, catalog number: S3264)

16. $\mathrm{KH}_{2} \mathrm{PO}_{4}$ (Sigma, catalog number: P9791)

17. $\mathrm{NaOH}$ (Sigma, catalog number: S5881)

18. Poly-L-lysine solution (Sigma, catalog number: P8920)

19. PIPES (Sigma, catalog number: V900404)

20. EDTA (Sigma, catalog number: V900106)

21. EGTA (Sigma, catalog number: E3889)

22. Liquid nitrogen

23. Spermine (Sigma, catalog number: S2876)

24. Spermidine (Sigma, catalog number: S0266)

25. DTT (Roche, catalog number: 3483-12-3)

26. Tween ${ }^{\circledR} 20$ (Sigma, catalog number: P1379)

27. BSA (VWR, catalog number: 0332)

28. DAPI (Sigma, catalog number: D8417)

29. Primary Antibodies

DiMethyl-Histone H3-K9 Rabbit pAb antibody (Abclone, catalog number: A2359) (at a dilution of 1:50 in blocking buffer)

30. Secondary Antibodies

Alexa Fluor 555-conjugated Goat Anti-Rabbit IgG $(\mathrm{H}+\mathrm{L})$ antibody (Abclone, catalog number: AS058) (at a dilution of 1:100 in blocking buffer)

31. 10x PBS (see Recipes)

32. $10 x$ Buffer $A$ (see Recipes)

33. Spermine stock (see Recipes)

34. Spermidine stock (see Recipes)

35. 2x Buffer A (see Recipes)

36. Blocking Buffer (see Recipes)

37. 1x Buffer A (see Recipes) 


\section{Equipment}

1. Pipette (Eppendorf)

2. Vacuum pump

3. Rotary shaker (Kylin-Bell Lab Instruments, ZD-2008)

4. Tweezers

5. Fluorescence Microscope (Nikon, model: Eclipse Ci-S)

6. Super High Pressure Mercury Lamp (Nikon, model: C-SHG1)

7. Incubator (Yamato, IC412C)

\section{Software}

1. ImageJ64 software (National Institute of Health)

2. Nis-Elements F64-bit (Nikon)

\section{Procedure}

A. Procedure for fixing maize embryos

1. Harvest 14 DAP ears and fix them as soon as possible after harvesting. Separate embryos from maize kernel cut parallel to the shaft with a scalpel. Submerge embryos in 1x PBS in $2 \mathrm{ml}$ Eppendorf tubes which are kept on ice during collecting to prevent embryo protein from degrading. After collecting, discard the 1x PBS with a pipette. To remove the endosperm, wash the embryos in the same tubes with $1 \mathrm{ml} 1 \times$ PBS, inverting 3-5 times, and then discard 1x PBS with a pipette. Do this three times (Video 1).

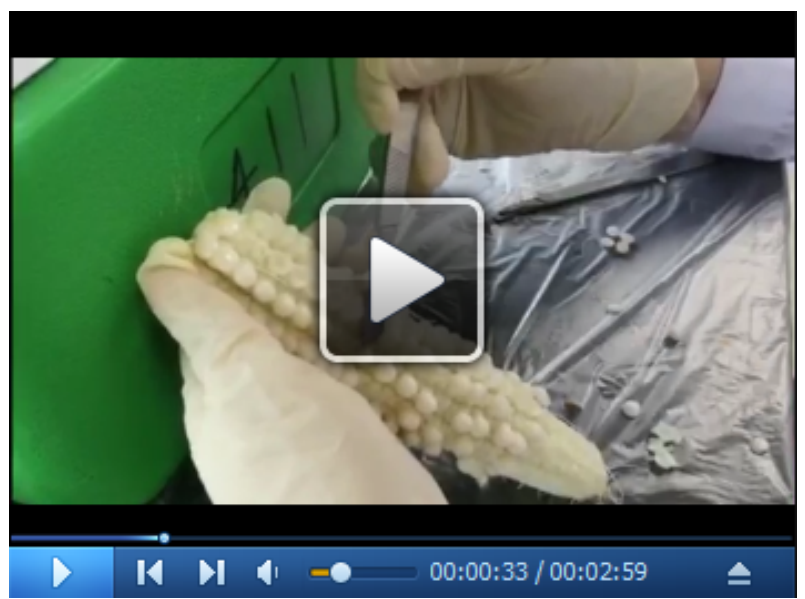

Video 1. Video of dissection procedure

2. Transfer the embryos to a $35 \mathrm{~mm}$ Petri dish containing $2 \mathrm{ml}$ of $1 \times$ Buffer $\mathrm{A}$. Add $1 \mathrm{ml}$ of $2 x$ Buffer A and $1 \mathrm{ml}$ of $16 \%$ formaldehyde to a final concentration of $4 \%$ formaldehyde in $1 x$ Buffer A. Fix 
embryos for 30 min at room temperature in a vacuum pump.

3. Discard liquid with a pipette and wash embryos in $2 \mathrm{ml}$ of $1 \times$ Buffer $A$ on a rotary shaker at room temperature 3 times for 15 min each.

4. Transfer embryos to $2 \mathrm{ml}$ Eppendorf tubes containing $1 \mathrm{ml}$ of fresh $1 \mathrm{x}$ buffer $\mathrm{A}$ with tweezers. Embryos can be used immediately or stored in Eppendorf tubes at $4{ }^{\circ} \mathrm{C}$ for several months.

B. Procedure for slide preparation (see Video 2 for details)

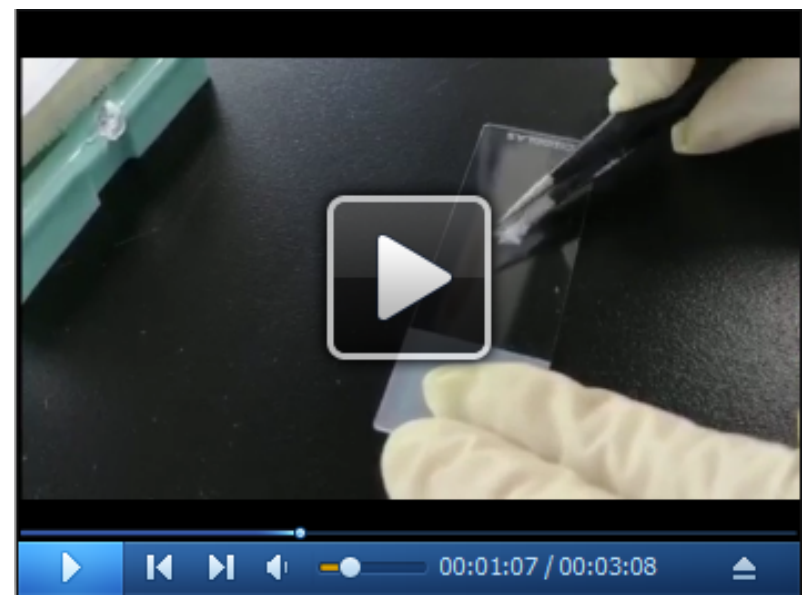

Video 2. Video of slide preparation

1. To improve cell adherence, drop $10 \mu \mathrm{l}$ of poly-L-Lysine solution onto a microscope slide and spread it uniformly with a coverslip.

2. Transfer an embryo onto the microscope slide containing a drop of buffer A with tweezers, and then squash it thoroughly using tweezers.

3. Place a coverslip on the drop, turn over the slide, and try to smash it with a pencil wrapped with several layers of Parafilm so that the cells distribute uniformly .Then the slide is wrapped in paper and strongly pressed with an eraser.

4. Using large tweezers, put the slide softly into liquid nitrogen until the bubbling sound stops. Note: Be sure to use the appropriate protective equipment when working with liquid nitrogen.

5. Take the slide out of liquid nitrogen and remove the slide immediately.

C. Procedure for Immunostaining

1. Put $50 \mu \mathrm{l}$ primary antibody onto the slide and cover with a piece of parafilm cut to the size of a coverslip.

2. Incubate the samples at $37{ }^{\circ} \mathrm{C}$ for at least $1 \mathrm{~h}$ or at $4{ }^{\circ} \mathrm{C}$ overnight in a slide incubation box or a wet chamber like a box with wet tissue on the bottom to avoid light.

3. Remove Parafilm coverslips with tweezers softly to avoid attrition and wash the slides with $1 x$ PBS with $1 \%$ Tween ${ }^{\circledR} 20$ four times, 10 min each in a staining jar on the shaker softly, and then let it dry naturally in the air. 
4. Incubate the samples with $50 \mu \mathrm{l}$ secondary antibody at $37^{\circ} \mathrm{C}$ for $1 \mathrm{~h}$ in a slide incubation box to avoid the light.

5. Remove Parafilm coverslips with tweezers softly avoid attrition and wash the slides 3 times with 1x PBS with 1\% Tween ${ }^{\circledR} 20$ and 1x PBS once, 10 min each in a staining jar on the shaker softly and then let it dry naturally in the air.

6. Apply $8 \mu \mathrm{l}$ of DAPI and cover the slides with a coverslip to avoid the light. The slide can be observed immediately after applying DAPI.

7. Observe slides under a fluorescence microscope equipped with image acquisition software, NisElements F64-bit.

8. Figure 1 shows a representative image, which was processed using ImageJ64 software.
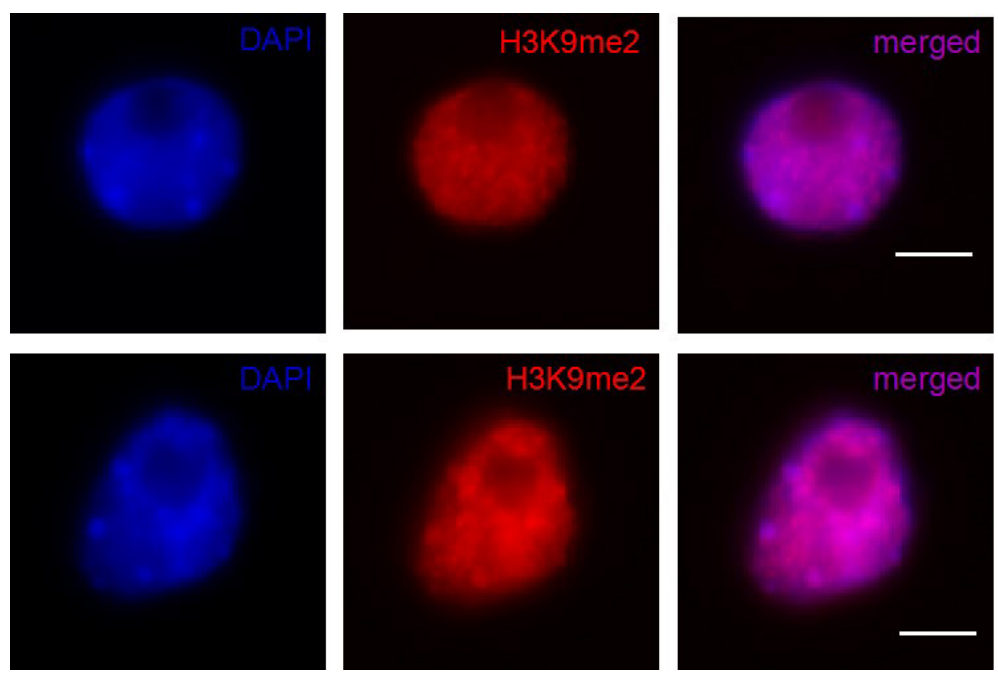

Figure 1. Immunolocalization of DiMethyl-Histone H3-K9 antibody in the wild type. DAPI staining is used to indicate the chromosomes. Scale bars $=5 \mu \mathrm{m}$.

\section{Notes}

1. Fresh embryos separated from maize kernel can be temporarily stored in 1x PBS on ice to protect proteins from degradation.

2. The exact stage of the embryos does not depend only on the days after pollination, but also on the conditions of growth and pollination.

3. The specificity of the primary antibody should be tested by Western blot prior to this protocol.

\section{Recipes}

1. $10 x$ PBS

$\mathrm{NaCl} 80 \mathrm{~g}$

$\mathrm{KCl} 2.0 \mathrm{~g}$

$\mathrm{Na}_{2} \mathrm{HPO}_{4} 14.4 \mathrm{~g}$ 
$\mathrm{KH}_{2} \mathrm{PO}_{4} 2.4 \mathrm{~g}$

Adjust the $\mathrm{pH}$ to 7.4 with $\mathrm{NaOH}$

Sterilize by autoclaving, store at $4{ }^{\circ} \mathrm{C}$

2. $10 x$ Buffer $A$ salts

$50 \mathrm{mM}$ PIPES

$800 \mathrm{mM} \mathrm{KCl}$

$200 \mathrm{mM} \mathrm{NaCl}$

20 mM EDTA

5 mM EGTA

Adjust the $\mathrm{pH}$ to 6.8 with $\mathrm{NaOH}$

Sterilize by filtration, store at $4{ }^{\circ} \mathrm{C}$

3. Spermine stock

0.4 M Spermine

50 mM PIPES

Adjust the $\mathrm{pH}$ to 7.0 with $\mathrm{HCl}$, store at $-20^{\circ} \mathrm{C}$

4. Spermidine stock

$0.4 \mathrm{M}$ Spermidine

50 mM PIPES

Adjust the $\mathrm{pH}$ to 7.0 , store at $-20^{\circ} \mathrm{C}$

5. $2 x$ buffer $A(500 \mathrm{ml})$

10x buffer $A$ salts $(100 \mathrm{ml})$

Spermine stock $(0.5 \mathrm{ml})$

Spermidine stock $(1.25 \mathrm{ml})$

2 mM DTT

640 mM Sorbitol

Autoclaved water (to $500 \mathrm{ml}$ final volume)

Store at $4{ }^{\circ} \mathrm{C}$

6. Blocking Buffer $(50 \mathrm{ml})$

1 mM EDTA

BSA $1.5 \mathrm{~g}$

Tween $^{\circledR} 2050 \mu \mathrm{l}$

Note: Divide into $1 \mathrm{ml}$ aliquots, freeze and store at $-20^{\circ} \mathrm{C}$.

7. $1 \times$ buffer $A(50 \mathrm{ml})$

2x Buffer A (25 ml)

Autoclaved water (to $50 \mathrm{ml}$ final volume), store at $4{ }^{\circ} \mathrm{C}$

\section{Acknowledgments}

This work was supported by grants from National Natural Science Foundation of China (31671277). 
This protocol is adapted from Chromatin immunoprecipitation for studying chromosomal localization of meiotic proteins in maize (He Y, Sidhu G, Pawlowski WP. Methods Mol Biol. 2013; 990:191-201. doi: 10.1007/978-1-62703-333-6_19).

\section{Competing interests}

The authors declare that they have no competing interests.

\section{References}

1. Bannister, A. J. and Kouzarides, T. (2011). Regulation of chromatin by histone modifications. Cell Res 21(3): 381-395.

2. Capuano, F., Mulleder, M., Kok, R., Blom, H. J. and Ralser, M. (2014). Cytosine DNA methylation is found in Drosophila melanogaster but absent in Saccharomyces cerevisiae, Schizosaccharomyces pombe, and other yeast species. Anal Chem 86(8): 3697-3702.

3. Chen, X. and Zhou, D. X. (2013). Rice epigenomics and epigenetics: challenges and opportunities. Curr Opin Plant Biol 16(2): 164-169.

4. De Paula, C. M. P. and Techio, V. H. (2014). Immunolocalization of chromosome-associated proteins in plants - principles and applications. Bot Stud 55(1): 63.

5. Fransz, P., Armstrong, S., Alonso-Blanco, C., Fischer, T. C., Torres-Ruiz, R. A. and Jones, G. (1998). Cytogenetics for the model system Arabidopsis thaliana. Plant J 13(6): 867-876.

6. Kim, J. K., Samaranayake, M. and Pradhan, S. (2009). Epigenetic mechanisms in mammals. Cell Mol Life Sci 66(4): 596-612.

7. Pawlowski, W.P., Grelon, M. and Armstrong, S. (2013). Plant Meiosis. Vol 990. Hat field, Hertfordshire, AL10 9AB, UK: Humana Press, Totowa, NJ.

8. Springer, N. M. and Schmitz, R. J. (2017). Exploiting induced and natural epigenetic variation for crop improvement. Nat Rev Genet 18(9): 563-575. 